\title{
Sustainable Environmental Practices and Financial Performance Relationships. Are they moderated by Cash Resources? Evidence from Alternative Investment Market in the UK.
}

\author{
Danquah Jeff Boakye ${ }^{1}$, Gabriel Sam Ahinful ${ }^{2}$ and Randolph Nsor-Ambala ${ }^{3}$ \\ ${ }^{1}$ Department of Accountancy, Koforidua Technical University \\ P.O. Box 981,Koforidua, Eastern Region - Ghana \\ Email:jeffboakye@yahoo.com \\ 2Directorate of Finance, Takoradi Technical University \\ P.O Box 256 Takoradi, Western Region - Ghana \\ Email:gabrielabinfu@yahoo.com \\ 3 Department of Accounting and Finance, GIMPA, Accra, Ghana \\ Email:nsor-ambala@gimpa.edu.gh
}

\begin{abstract}
This paper examines how cash resources affect the sustainable environmental practices and financial performance of firms listed on the Alternative Investment Market (AIM) in the United Kingdom (UK). The study adopts Ordinary Least Square (OLS) regression model on 201 quoted Small and Medium Enterprises (SMEs) on the UK Alternative Investment Market (AIM) from 2011 to 2016. Consistent with our predictions and confirms with the assertions of the resource-based view, the study documents that cash resources have a positive impact on sustainable environmental practices and financial performance relationships. However, the direction of the regression coefficient was not the same for accounting (ROA) and market-based (Tobin's q) measures of financial performance. Whereas the moderating impact between cash resources and sustainable environmental practices for ROA was negative, the relationship was positive in the case of Tobin's q. The study, therefore, concluded that where excessive cash are employed in the management and implementation of environmental sustainability, the financial returns may not be favourable. However, efficient utilisation of cash resources may positively impact on sustainable environmental practices and financial performance relationships. The study also documented that unconstraint firms have a higher probability of benefiting financially from environmental sustainability measures than cash constraint firms.
\end{abstract}

Keywords: Sustainable Environmental Practices, Environmental Policy, Resource-based view, Financial Performance, SMEs, AIMs.

Citation: Danquah Jeff Boakye ${ }^{1}$, Gabriel Sam Ahinful ${ }^{2}$ and Randolph Nsor-Ambala ${ }^{3}$. Sustainable Environmental Practices and Financial Performance Relationships. Are they moderated by Cash Resources? Evidence from Alternative Investment Market in the United Kingdom., 2020; 5(1): 14-29.

Received: (February 15, 2020)

Accepted: (March 31, 2020) 


\subsection{Introduction}

Issue of environmental sustainability has taken centre stage in many political and business platforms in recent years. Thurner \& Proskuryakova (2014) indicated that environmental issues had become a significant part of management decision. Similarly, Wiengarten \& Pagell, (2012) emphasised that sustainability practices, as part of sustainability management, are now an essential part of the thoughts and practices of researchers and operational managers. However, to encourage business practitioners to pursue sustainable environmental practices, it is essential that such environmental practices also impact positively on their financial performance. Trumpp \& Guenther (2017), for instance, argued that if positive association are established for sustainable policies and the bottom-line, it will encourage businesses to engage in sustainable environmental practices.

Although there is a trade-off between good environmental practices which one side is the benefits from reduced pollution and clean environment, on the other hand, is the higher cost of complying with strict environmental practices which may reduce competitiveness. However, Ambec et al. (2013) argued that sustainable environmental practices might trigger innovation which may offset the cost of investment and impact favourable on profitability. In line with this argument, various empirical studies have established a positive correlation between environmental and financial performance relationships. For instance, studies such as Christmann (2000), Carter, et al. (2000), Melnyk et al. (2003) Clemens (2006) Montabon et al. (2007), López-Gamero et al. (2009) have discovered a positive link between sustainability policies and financial outcomes. However, a significant number of these research have concentrated on large companies listed on the main markets (Filbeck \& Gorman, 2004; Earnhart \& Lizal, 2007; Clark et al., 2015) although various evidence exist that most pollution emanates from SMEs. Notably, Environment Agency (2003) estimated that SMEs create about $60 \%$ of waste from commercial sources in the UK and Hillary \& Burr, (2011) indicated that the sheer number of SMEs with a significant number in manufacturing has the potential to exert pressure on the environment.

Various reasons have been cited as to why most studies have not concentrated on green practices and profitability relationships of small and medium firms. The key reason has been attributed to the fact that SMEs lack resources and hence unlikely to pursue sustainable environmental practices. Company's size is considered as essential and by implication, larger companies have an advantage in introducing sustainable, environmentally friendly innovations than SMEs (Thurner \& Proskuryakova, 2014). The study will, therefore, be one of the few studies to consider the plausible effect of financial constraints on environmental sustainability and financial implications. Although many studies (e.g. Aiyub, Arifin, Awang, \& Jahi, 2009; Hillary \& Burr, 2011)have recognised that cash constraints affect SMEs' ability to implement proactive environmental practices, it has not been tested empirically. Others (see. Christmann 2000, López-Gamero et al. 2009) have indicated that the availability of resources moderate environmental and financial performance relationships. It is argued that the existence of cash resources can enhance a firm's ability to acquire other resources such as pollution abatement equipment to introduce innovative environmental practices that can impact positively on profitability (Trumpp et al., 2013). Most AIM listed firms are new, and evidence suggests that most new firms are usually cash-constrained as they lack market reputation to access finance more easily (Berger and Udell, 
1995; Arslan, Florackis and Ozkan, 2006). Thus, aside from the fact that this study concentrates on SMEs it also provides evidence for the first time as to whether the availability of cash resource influences the link between environmental sustainability and profitability which has not been empirically tested in the existing studies. The study objectives are, therefore stated as follows:

- To assess the impact of cash resources on Sustainable Environmental Practices (SEP) and Financial Performance (FP) relationships for listed SMEs.

- To examine the effect of financial resources on environmental sustainability policies and financial outcomes for cash constraint and unconstraint firms.

\subsection{Sustainable Environmental Practices and Financial Performance}

The resource-based view (RBV) has been adopted for this study. The reason for employing the RBV is based on the premise that cash (resource) endowed firms are likely to engage in green practices than less resource endowed firms. It has been argued that SMEs are resource constraint and unlikely to pursue green investments and such initiatives are likely to reduce profitability (Aiyub et al., 2009). However, others have argued otherwise that small and medium firms have unique assets such as plough back funds, uncomplicated capital structure, the entrepreneurial skills of management which enable them to have a competitive edge by adopting of greenoriented investment (López-Gamero et al., 2009).

The RBV perceives corporations as being successful through the acquisition of a unique set of resources (Thurner \& Proskuryakova, 2014). Thurner and Proskuryakova (2014) give resources as consisting of productive knowledge that offers a community opportunity to learn and use the knowledge for commercial purposes. In the view of Hart (1995) to create sustainable competitive advantage, the firm's capabilities and competencies should be supported by resources that cannot be easily imitated. Hart (1995) identified the features of firm resources as one that can sustain competitive advantage, non-substitutability, rare, specific to a particular firm and not easy to replicate. Valuable resources have unique capabilities in fulfilling organisational objectives and are challenging to be accomplished through other means. Barney (1991) argued that unique resources is firm-specific and should not be widely available to the industry. It should be aligned to a particular firm and therefore difficult to transfer or replicate by another. Hart (1995) indicated that an essential attribute of the resources for competitiveness is that it must be difficult to replicate. The resources that are hard to imitate are tacit, complex, skilled based and people intensive, invisible and are achieved upon learning by doing and are usually developed through experience and refined through practice (Hart, 1995).

Resources that are unique, valuable and inimitable is likely to be the needs of the society and as such resources that address cleaner environment will establish legitimacy with the society and improve competitiveness and profitability Russo \& Fouts, 1997). López-Gamero et al. (2009) also emphasised that sustainable environmental practices encourage the development of new resources. They argued that by pursuing sustainable environmental practices, firms could develop innovative technology that involves low production emission 
concerning other competitors. Such firms may obtain first-mover advantages as a result of a positive environmental image and as a result, may enhance its competitiveness and profitability.

To invest in such environmentally sustainable technology and other unique environmental resources that can impact on profitability may require the availability of cash resources. It is argued that higher cash reserve affects a firm's ability to undertake profitable investments. The empirical study by Scheuten, (2014), for instance, recorded a positive link between cash flow that is internally generated and investment. However, different arguments for cash constraint and unconstraint firms sensitivities to investment have been advanced. Fazzari, Hubbard and Petersen (2000) discovered that where businesses that have a problem obtaining external funding have a stronger link between cash holding and value-added projects. Almeida et al. (2004) documented that small firms and non-dividend payers as well as those firms that have difficulties accessing credits mostly keep more cash balances out cash flow. Denis \& Sibilkov (2010) emphasised that higher level of cash reserves are positively associated with an investment in cash-constrained firms that usually need higher hedging and the correlation between investment and return is stronger for firms with cash difficulties than those with no cash difficulties. They explained that higher cash reserves allow businesses to pursue a value-enhancing project, which otherwise might be overlooked. Thus, whereas constrained firms are likely to invest in sustainable environmental projects which might not be related to their core activities and the associated benefits thereof, such opportunities might be overlooked by unconstrained firms. This line of argument has been supported by empirical findings of Reyes-Rodríguez et al. (2014) which identified that although SMEs face cash constraint, the 14 years' longitudinal study found that the motivation for SMEs to engage in sustainable environmental practices stems from the expected competitive advantage and financial performance. Therefore, whereas larger companies, which are mostly not constrained by cash may ignore investments in sustainable environmental practices due to their insensitivity to investment, this may be exploited by SMEs to obtain the associated financial benefits.

However, a different view has been offered on investment sensitivities between constraint and unconstraint firms. Cleary (2006), for instance, found that there is no monotonic association between the extent of external market reaction and cash resources. The study documented that unconstraint firms are more sensitive to cash flow than constrained and partially constrained firms. These findings have been supported by Cleary (1999) and, Cleary (2006) who identified a reverse relationship between investment cash flow sensitivities and constraints firm. Thus, whereas most constraints firms have the lowest sensitivities to investment cash flow, unconstraint firms are highly sensitive to investment cash flow. Cleary (2006) findings have also been emphasised by Aiyub et al. (2009) that sustainable environmental practices including the adoption of ISO 14001 are difficult for SMEs to implement due to cash flow and other constraints. They reiterated that SMEs face pressure on resources, notably financial resources and therefore tend to pursue projects with short payback periods. Sustainable environmental practices such as adoption and implementation of ISO 14001, which involve long-term investment tend to create a higher risk for SMEs if they are not offered incentives in the short-term. Therefore, SMEs are mostly financially constrained may not be sensitive to sustainable environmental investment. However, AIM listed firms comprise both old and new firms which may be constrained or unconstrained by financial resources. Therefore, assessing the impact of sustainable 
environmental practices and financial performance for firms with cash flow difficulties and those with no cash flow difficulties is likely to provide new evidence on environmental and financial performance relationships.

\subsection{Methodology}

The sample consists of 201 SMEs selected from 1049 companies listed on the AIM as at February 2016 from 2011 to 2016 that reported on their environmental policies and practices. The selected firms were spread across 26 different industries. Firms with presumed very minimal pollution level such as banks and financial services, (Konar \& Cohen, 2001) were not included as they are based on different disclosure and regulatory requirements (Ntim \& Soobaroyen, 2013). In line with the argument from Gómez-Bezares, et al., (2017) firms selected are those consistently report on their green policies as inferior firms usually will not reveal their poor sustainability engagement.

The study employed two dependent variables, namely ROA and Tobin's $q$ as financial performance metrics. In line with Hagel et al. (2013), ROA was used as it is considered as the most effective and broad measure of financial performance. In the case of market-based, which serves as a robustness check to the primary dependent variable ROA, Tobin's q, which reflect shareholder value analysis, was considered. Cash balance was used as a moderating variable as financial resources are regarded as one of the critical resources that determine the adoption of environmental sustainability. The dependent and the moderating variables were selected from Amadeus and Fame database.

In line with DEFRA (2013) guidelines, sustainable environmental practices (independent variables) used is Environmental Management Practices (EMP) which is composite of Energy, Waste Management, Pollution Control (GHG), Material and Resource Efficiency, Compliance and Stakeholder Engagement. Content analysis was adopted to handpicked sustainable environmental practices from company annual reports. Companyspecific factors and corporate governance variables were controlled under the study. Firm's size was control as the existence of economies of scale may impact on profitability (Elsayed and Paton, 2009). The industry effect was also controlled as existing evidence suggests that industry impact on profitability hence the need to be controlled (Horváthová, 2012). Risk tolerance (leverage) was also controlled as a capital structure impact on profitability (Li and Hwang, 2011). Liquidity was controlled as it is argued that shortening the cash conversion cycle can impact on financial performance (Martínez-Ferrero \& García-Sánchez, 2017). The current ratio was used as a measure of liquidity, and like the leverage and the number of employees, the liquidity ratios were obtained from the Amadeus and Fame database. In relation to the corporate governance variables, Board size represented the total number of directors, non-executive directors on board and CEO remuneration were employed. This information was handpicked from the financial statements of the selected firms.

The empirical model is given below:

$F P_{i t}=\beta_{0}+\beta_{1} S E P_{i t}+\beta_{2}$ Controls $_{i t}+\beta_{3} C_{i t}+\beta_{4}\left(S E P_{i t} * C_{i t}\right)+\mu_{i t}+\lambda_{i t}+\varepsilon_{i t}$ Where FP is the dependent variable which is measured using returns on assets (ROA) and Tobin's q, SEP is the independent variables which are the composite of Energy, GHG, Waste, Compliance, Materials and Resource Efficiency and Stakeholder. C represents cash resources (Cash), and $\mathrm{SEP}^{*} \mathrm{C}$ describes the interacting variable sustainable environmental practices and cash resources. Control variables indicated by controls are firm size (Size), Liquidity, Gearing, Board Size, Number on non-executive directors (NEDs), CEO Remuneration (CEO Rem), 
Industry Effect and Year Effect. $\beta 1, \beta 2, \beta 3$ and $\beta 4$ are the regression coefficients. The subscript $i$ represents the nth company $(i=1 \ldots 201)$, and $t$ is for the year $(t=1, . .6)$. $\mu$ i denotes unobservable heterogeneity (individual effects) that is specific for each firm, $\lambda$ t represents the parameters of time dummy variables, and sit means the error term. A fixed-effect regression model was employed.

\subsection{Results and Discussions}

\subsection{Descriptive Statistics}

This summary statistics for the period, 2011 to 2016 is reported in this section the sampled firms. The report gives a mean of $0.07(7 \%)$ and a standard deviation of $0.16(16 \%)$ for ROA. The minimum of ROA is -0.92 ($92 \%)$, and the maximum is $0.84(84 \%)$ indicates that there is a wide variation in the accounting profit of AIM listed companies. The median value of $0.0657(7 \%)$ is almost the same as the mean suggests that the distribution is symmetric as shown in the skewness and kurtosis which is within the range of 3 and 10 as indicated by Kline (2010). The lower profit margin recorded confirms evidence from prior studies such as Afrifa (2013), which documented negative profits for small and medium companies listed on AIM. The Tobin's q, on the other hand, gives a mean value of 1.83 a minimum of 0.12 and a maximum of 40.58 and also showing extensive variation similar to the ROA.

The summary statistics for the independent variables, Sustainable Environmental Practices (SEP) gives a mean of the value of 7.31, a standard deviation figure of 5.6, and a with a median number of 6 . The mean value of 7.31 indicates SEP measures represented by quantitative disclosures are minimal. The mean of 7.31 also suggests that less than $25 \%$ of AIM listed firms may only report on their environmental sustainability measures as the maximum disclosure item was 30 . The minimum of 0 for the SEP implies that there was no disclosure for some years by some companies. The summary statistics also showed that Cash and cash equivalent also have wide variability with a range of $£ 0.00$ to $£ 572 \mathrm{~m}$ similarly to the ROA and Tobin's $\mathrm{q}$. the detail summary statistics are given in table one below.

Table 1: Summary Statistics

Table one reports summary statistics for dependent and independent variables employed in estimating the sustainable environmental policies and financial performance from 201 listed companies on the Alternative Investment Market in the period 2011-2016. It gives the dependent variables; return on assets (ROA), and Tobin's q. This is followed by explanatory variables which are made up of the composite of sustainable environmental practices (SEP) and the disaggregated SEP in order of Energy, Greenhouse Gases (GHG), Waste, Materials and Resource Efficiency (Materials), compliance to environmental regulations (Compliance) and stakeholder engagement (Stake). The control variables are also presented in order of Size, Liquidity, Gearing, Board Size, number of non-executive directors (NEDS) and CEO Remuneration (CEORem). The rests are the moderating variables growth and cash. 


\begin{tabular}{|l|rrrrrrrr|}
\hline Variables & Observation & Mean & Std Dev & Min & Max & Median & Skewness & Kurtosis \\
\hline Dependent & & & & & & & & \\
ROA & 1044 & 0.0699551 & 0.158 & -0.92 & 0.8351 & 0.0306 & -0.86412 & 5.47476 \\
Tobin Q & 897 & 1.834517 & 2.821327 & 0.12 & 40.58 & 0.96 & 7.266498 & 79.51813 \\
\hline Independent & & & & & & & & \\
SEP & 1184 & 7.31 & 5.60 & 0 & 28 & 6 & 1.24 & 4.17 \\
Energy & 1184 & 0.8268581 & 1.41287 & 0 & 5 & 0 & 1.790587 & 5.143679 \\
GHG & 1184 & 0.8699324 & 1.425516 & 0 & 5 & 0 & 1.725508 & 5.064315 \\
Waste & 1182 & 0.7436548 & 1.175292 & 0 & 5 & 0 & 1.853122 & 6.213871 \\
Materials & 1183 & 1.143702 & 1.553766 & 0 & 5 & 0 & 1.173376 & 3.157637 \\
Compliance & 1183 & 3.171598 & 1.484883 & 0 & 5 & 3 & -0.3688 & 2.307921 \\
Stakeholders & 1183 & 0.5490694 & 0.875997 & 0 & 5 & 0 & 1.173376 & 3.157637 \\
Size & 1090 & 460 & 795 & 1 & 5611 & 138 & 3.031281 & 13.53031 \\
Liquidity & 1147 & 3.704965 & 8.906794 & 0.01 & 170.26 & 1.33 & 8.967828 & 129.0418 \\
Gearing & 1122 & 47.28767 & 70.42343 & 0 & 844.34 & 25.85 & 4.572813 & 35.67667 \\
Board Size & 1107 & 6.034327 & 1.935837 & 0 & 13 & 6 & 0.332318 & 3.442358 \\
NEDS & 1107 & 3.333333 & 1.493809 & 0 & 11 & 3 & 0.751142 & 4.196321 \\
CEO Remu & 1064 & 336710 & 280220 & 12000 & 3731302 & 254447 & 3.771331 & 31.78104 \\
Growth & 1075 & 17.57 & 67.17 & 85.42 & 900.37 & 5.09 & 5.78 & 51.59 \\
Cash & 1092 & 16501 & 43401 & 0 & 572778 & 4278 & 6.40 & 55.76 \\
\hline
\end{tabular}

\subsection{Correlation Analysis}

The correlation matrix showed in table 2 revealed that ROA has a significant positive correlation with all measures of SEP as well as the composite. However, Tobin's q did not show a significant relationship with the SEP and the disaggregated aspects of SEP except compliance which revealed a significant negative relationship. The correlation matrix also revealed that there was no issue multicollinearity. Field (2013) suggested that correlation among the predictors are not considered problematic unless they exceed .90 , and no such case was recorded. 


\section{Table 2: Correlation Matrix}

Table 2 reports the correlation matrix for dependent and independent variables used in estimating the link between sustainable environmental practices and financial performance. The variables employed are return on assets (ROA) and Tobin's q for dependent variables. The independent variables, Sustainable Environmental Practices (SEP) are Energy Efficiency Practices (Energy), Greenhouse Gases (GHG), Waste Management (Waste), Stakeholder Engagement (Stake), Material and Resource Efficiency (Mat), Compliance to environmental regulations (COMP), Firm Size (Size), Liquidity (Liquidity) Board Size (B Size), Number on non-executive directors (NEDs) CEO Remuneration (CEO Rem) and Cash and Cash

Equivalents (Cash).

\begin{tabular}{|c|c|c|c|c|c|c|c|c|c|c|c|c|c|c|c|c|}
\hline & ROA & Tobin $\mathrm{q}$ & SEP & Energy & GHG & Waste & Stake & Mat & Comp & Size & Liquidity & Gearing & B Size & NEDS & $\begin{array}{l}\text { CEO } \\
\text { Rem }\end{array}$ & Cash \\
\hline ROA & 1 & & & & & & & & & & & & & & & \\
\hline Tobin q & $0.116^{*}$ & 1 & & & & & & & & & & & & & & \\
\hline SEP & $0.493^{*}$ & -0.036 & 1 & & & & & & & & & & & & & \\
\hline Energy & $0.372^{*}$ & -0.032 & $0.748^{*}$ & 1 & & & & & & & & & & & & \\
\hline GHG & $0.396^{*}$ & -0.017 & $0.797 *$ & $0.585^{*}$ & 1 & & & & & & & & & & & \\
\hline Waste & $0.354^{*}$ & -0.023 & $0.719 *$ & $0.443^{*}$ & $0.516^{*}$ & 1 & & & & & & & & & & \\
\hline Stake & $0.303^{*}$ & 0.019 & $0.546^{*}$ & $0.269^{*}$ & $0.534^{*}$ & $0.293^{*}$ & 1 & & & & & & & & & \\
\hline Mat & $0.379 *$ & 0.009 & $0.780^{*}$ & $0.552 *$ & $0.537 *$ & $0.544^{*}$ & $0.285^{*}$ & 1 & & & & & & & & \\
\hline Comp & $0.240^{*}$ & $-0.09 *$ & $0.544 *$ & $0.190^{*}$ & $0.276^{*}$ & $0.214^{*}$ & $0.291 *$ & $0.227^{*}$ & 1 & & & & & & & \\
\hline Size & $0.253^{*}$ & -0.048 & $0.335^{*}$ & $0.242^{*}$ & $0.283^{*}$ & $0.223^{*}$ & $0.210^{*}$ & 0.212 & $0.184^{*}$ & 1 & & & & & & \\
\hline Liquidity & -0.137 & $0.115^{*}$ & -0.117 & $-0.14 *$ & $-0.11 *$ & $-0.11 *$ & -0.003 & $-0.13^{*}$ & 0.018 & $-0.18 *$ & 1 & & & & & \\
\hline Gearing & 0.05 & 0.046 & 0.054 & 0.054 & 0.047 & 0.001 & -0.001 & $0.059^{*}$ & 0.044 & $0.163^{*}$ & $-0.14^{*}$ & 1 & & & & \\
\hline B Size & $0.167 *$ & -0.026 & $0.138 *$ & $0.132 *$ & $0.119 *$ & $0.071 *$ & $0.148^{*}$ & $0.073 *$ & 0.044 & $0.125^{*}$ & $-0.12 *$ & $0.053^{*}$ & 1 & & & \\
\hline NEDS & $0.092^{*}$ & 0.016 & $0.088^{*}$ & 0.047 & 0.026 & $0.061 *$ & $0.069 *$ & 0.034 & $0.129 *$ & $0.076^{*}$ & 0.03 & -0.008 & $0.697 *$ & 1 & & \\
\hline CEO Rem & $0.175^{*}$ & -0.026 & $0.222 *$ & $0.208^{*}$ & $0.259 *$ & $0.097 *$ & $0.117 *$ & $0.168^{*}$ & 0.048 & $0.334 *$ & $-0.07 *$ & 0.059 & $0.270^{*}$ & $0.196^{*}$ & 1 & \\
\hline Cash & $0.001 *$ & -0.001 & $0.105^{*}$ & $0.104^{*}$ & $0.169^{*}$ & $0.025^{*}$ & 0.058 & 0.046 & 0.023 & $0.314^{*}$ & 0.036 & 0.019 & $0.124^{*}$ & $0.107 *$ & $0.230^{*}$ & 1 \\
\hline
\end{tabular}

Significance levels $\left(^{*}\right)$ are designated between $1 \%$ and $10 \%$. 


\subsection{Regression Analysis}

\subsubsection{The Impact of Cash Resources on SEP and FP Relationships}

The primary study objective is to establish whether the existence of a large cash balance (cash and cash equivalent) influences environmental and financial performance relationships. The OLS regression model presented in Table 3 revealed a positive and significant link between environmental sustainability and profitability represented by ROA, and also cash resources and ROA. Regarding Tobin's q, the significant but negative relationship with SEP was identified. It also showed that Tobin's q and cash were negative but not significant. More importantly, the study also discovered that cash resources moderate the relationship between SEP and FP under both profitability measure and market measures represented by ROA and Tobin's q, respectively. However, concerning the ROA, the cash reserves moderate SEP negatively, whereas in respect of Tobin's q, cash reserves moderate SEP positively

Table 3: OLS Regression Results of the impact of Cash Resources on SEP and FP Relationship

Table 3 provides pooled OLS regression on Sustainable Environmental Practices (SEP) and financial performance (FP) relationships moderated by cash resources:

$F P_{i t}=\beta_{0}+\beta_{1} S E P_{i t}+\beta_{2}$ Controls $_{i t}+\beta_{3} C_{i t}+\beta_{4}\left(S E P_{i t} * C_{i t}\right)+\mu_{i t}+\lambda_{i t}+\varepsilon_{i t} . F P$ is the dependent variable represented by returns on assets (ROA) and Tobin's q. SEP is the independent variables which are the composite of Energy, GHG, Waste, Compliance, Materials and Resource Efficiency and Stakeholder. C represents cash resources (Cash), and SEP*C describes the interacting variable sustainable environmental practices and cash resources. Control variables are represented firm size (Size), Liquidity, Gearing, Board Size, Number of nonexecutive directors (NEDs), CEO Remuneration (CEO Rem), Industry Effect and Year Effect. $\beta 1, \beta 2, \beta 3$ and $\beta 4$ are the regression coefficients. The subscript $i$ represents the sample firms $(i=1 \ldots 201)$, and the subscript $t$ represents the year $(t=1, . .6) . \mu i$ is the unobservable firm heterogeneity (individual effects) applies to each firm, $\lambda t$ is the parameters of time dummy variables, and cit is the error term. The regression is modelled with robust fixed effects.

\begin{tabular}{lcc}
\hline \multirow{2}{*}{ VARIABLES } & $(1)$ & $(2)$ \\
SEP & ROA & Tobin's q \\
& $0.0249^{* * *}$ & $-0.0853^{* * *}$ \\
Cash & $(6.16)$ & $(-2.63)$ \\
& $0.0152^{* *}$ & -0.0557 \\
SEP*Cash & $(2.49)$ & $(-1.31)$ \\
& $-0.00154^{* * *}$ & $0.0118^{* * *}$ \\
Size & $(-3.33)$ & $(3.26)$ \\
& $0.0102^{* *}$ & -0.0127 \\
Liquidity & $(2.49)$ & $(-0.49)$ \\
& -0.00414 & $0.156^{* * *}$ \\
Gearing & $(-0.62)$ & $(3.91)$ \\
& $-0.0139^{* * *}$ & $-0.0511^{* *}$ \\
Board Size & $(-4.08)$ & $(-2.22)$ \\
& $0.00762^{* *}$ & -0.0431 \\
NEDS & $(2.22)$ & $(-1.54)$ \\
& $-0.00840^{* *}$ & 0.0461 \\
CEO Rem & $(-2.0)$ & $(1.40)$ \\
& 0.0155 & 0.0250 \\
& $(1.29)$ & $(0.47)$
\end{tabular}




\begin{tabular}{lcc} 
Industry Effect & Yes & Yes \\
Year Effect & Yes & Yes \\
Observation & 789 & 710 \\
R Squared & 0.3201 & 0.1246 \\
F Statistics & 16.53 & 5.58 \\
P Value & 0.03 & 0.668 \\
\hline \multicolumn{4}{c}{ t statistics in parentheses } \\
& $* * * \mathrm{p}<0.01,{ }^{* *} \mathrm{p}<0.05,{ }^{*} \mathrm{p}<0.1$
\end{tabular}

The above findings support the proposition that cash resources moderate sustainable green measures and profitability. Endrikat, et al. (2014) argued that redesigning of the production process and introduction of polluting abatement inputs require financial resources. Based on their argument on slack resource hypothesis, their empirical findings confirmed that the availability of financial resources influences sustainable environmental practices. Aiyub et al. (2009) reiterated that when company financial performance such as cash resources improves, slack resources are likely to be available to allow the company to undertake sustainable environmental practices to achieve superior financial performance. Similarly, Fauzi \& Idris (2009) also aver that the availability of firm resources more drives the implementation of socially responsible and sound environmental practices. Thus, by implication, companies with slack resources can undertake strategic environmental policies and execution to achieve superior financial outcomes.

However, as shown in Table 3 whereas the above argument holds for Tobin's q, based on the ROA although the results indicated both SEP and Cash resources individually positively influence performance, the interacting effect of SEP and cash on environmental and financial performance relationship is negative. This result might suggest that excessive investment of cash in sustainable environmental practices could cause disruption as the impact of SEP on FP could reach the optimal level and thereby resulting in decreasing financial performance. In line with Vijfvinkel et al. (2011) which asserted that although the society is prepared to pay a premium for environmental innovative and sustainable products, the increasing market for green-oriented products does not necessarily mean that firms that invest hugely on environmental sustainability will perform better financially. They reiterated becoming sustainable involved huge costs. Therefore, a different degree of environmental sustainability might be a better option than a firm that is fully sustainable.

\subsubsection{The Impact of Cash Reserves on SEP and FP relationships for Cash Constraint and Unconstraint Firms}

In addition to whether cash resources moderate sustainable environmental practices and financial performance relationships, the study also delved further as to whether cash constraint companies or unconstraint companies are more likely to benefit from sustainable environmental practices. The fixed-effect model revealed in table 4 indicates that there is a significant and positive association between SEP and FP for both constraint and unconstraint firms based on ROA. However, no significant link was identified under Tobin's q. There was also no significant effect of cash balance on financial indicators under both ROA and Tobin's Q. 
Table 4: OLS Regression results for SEP and FP Relationship for Cash Constraint and Unconstraint Firms

Table 5 reports the results of pooled OLS regression on Sustainable Environmental Practices (SEP) and financial performance (FP) relationships for cash constraint and unconstraint firms where constraint firms are represented by firms with a median cash balance of $\leq £ 4,278,000.00 . \quad F P_{i t}=\beta_{0}+\beta_{1} S E P_{i t}+\beta_{2}$ Controls $_{i t}+\mu_{i t}+\lambda_{i t}+$ $\varepsilon_{i t}$. Where FP is the dependent variable which is measured using returns on assets and Tobin's. SEP is the independent variables which are the composite of Energy, GHG, Waste, Compliance, Materials and Resource Efficiency and Stakeholder. Control variables indicated by Controls are firm size (Size), Liquidity, Gearing, Board Size, Number on non-executive directors (NEDs), CEO Remuneration (CEO Rem), Industry Effect and Year Effect. $\beta 1$ and $\beta 2$ are the regression coefficients. The subscript $i$ represents the firms, constraint, $(i=1 \ldots 100)$, and unconstraint $(i=1 \ldots 101)$, the subscript $t$ indicate the year $(t=1, . .6)$. pi denotes unobservable heterogeneity (individual effects) specific for each firm, $\lambda t$ represents time dummy variables, and sit is for the error term. Regressions models are based on robust fixed effects.

\begin{tabular}{lcccc}
\hline VARIABLES & $\begin{array}{c}\text { Unconstraint } \\
\text { ROA }\end{array}$ & $\begin{array}{c}\text { Unconstraint } \\
\text { Tobin's }\end{array}$ & $\begin{array}{c}\text { Constraint } \\
\text { ROA }\end{array}$ & $\begin{array}{c}\text { Constraint } \\
\text { Tobin's q }\end{array}$ \\
\hline SEP & $0.0142^{* * *}$ & 0.00639 & $0.00908^{* * *}$ & 0.0103 \\
& $(9.49)$ & $(0.67)$ & $(7.92)$ & $(1.28)$ \\
Cash & -0.00211 & 0.0237 & -0.00186 & 0.0536 \\
& $(-0.29)$ & $(0.46)$ & $(-0.30)$ & $(1.49)$ \\
Size & -0.0116 & $-0.117 * *$ & $0.0242^{* * *}$ & $0.0836^{* * *}$ \\
& $(-1.43)$ & $(-2.28)$ & $(5.24)$ & $(3.16)$ \\
Liquidity & -0.00818 & $0.199 * *$ & 0.00580 & $0.0861^{* *}$ \\
& $(-0.74)$ & $(2.37)$ & $(0.74)$ & $(2.15)$ \\
Gearing & $-0.0172^{* * *}$ & 0.0531 & $-0.0128 * * *$ & $-0.196^{* * *}$ \\
& $(-3.30)$ & $(1.65)$ & $(-2.86)$ & $(-5.00)$ \\
Board Size & $0.0137 * *$ & -0.0563 & 0.0583 & -0.0265 \\
& $(2.19)$ & $(-1.60)$ & $(1.41)$ & $(-0.69)$ \\
NEDS & -0.00635 & 0.0263 & $-0.0107 * *$ & 0.0203 \\
& $(-0.77)$ & $(0.62)$ & $(-2.16)$ & $(0.49)$ \\
CEO Rem & 0.0136 & 0.0850 & 0.0201 & 0.00726 \\
& $(0.60)$ & $(1.08)$ & $(1.60)$ & $(0.10)$ \\
Industry Effect & Yes & Yes & Yes & Yes \\
Year Effect & Yes & Yes & Yes & Yes \\
Observation & 381 & 341 & 408 & 369 \\
R Squared & 0.3167 & 0.1153 & 0.3688 & 0.2648 \\
F Statistics & 10.67 & 2.90 & 13.61 & 6.49 \\
P Value & 0.507 & 0.389 & 0.007 & 0.530 \\
\hline & t statistics in parentheses & & \\
& $* * * \mathrm{p}<0.01, * * \mathrm{p}<0.05, * \mathrm{p}<0.1$ & & \\
& & & &
\end{tabular}

Thus, both constraint and unconstraint firms, are likely to take the opportunity of the growing market for greenoriented products to enhance their financial performance. This result also confirmed the assertions by Fazzari et al. (1988) that higher cash holding has more impact on investment with constraints firms which requires more hedging needs than unconstraint firms. The results also do not deviate from the assertions of Allayannis and 
Mozumdar (2004), which argued that the impact on unconstraint firms would be more significant as they have the resources to undertake those investments. As shown in the empirical model reported in table 4, the impact of SEP on ROA for unconstraint firms is more significant than that of constraints companies. The findings have also been earlier confirmed by Aiyub et al. (2009) study, which discovered that larger companies with substantial financial resources benefited more from sustainable environmental practices than smaller companies that are resourcestrapped. Additionally, the result also establishes a link with theoretical and empirical studies that resources moderate environmental and financial performance relationships (Lopez-Gamero et al., 2009)

\section{Conclusion}

Many studies have discovered that resources, notably financial resources, affect SMEs ability to implement improved environmental practices. Aiyub et al. (2009) for instance, explained that availability of cash resources directly impacts on fund available for investment and the expectation is that firms with adequate financial resources are more likely to undertake more investment projects. Improved cash resources impact on the net worth and premium on external funding falls and thereby creating an opportunity for businesses to invest through external financing. However, the moderating impact of cash resource on sustainable environmental practices and financial performance relationships have not been considered by the existing studies, particularly in the case of AIM listed firms. This study, therefore, provides new evidence to the studies in this area by showing the impact of cash resources on sustainability practices, specifically environmental practices and financial performance relationships.

The study, therefore, offers several implications. First, the study revealed that environmental reporting by AIM listed firms is minimal. Although over 1000 firms are listed on the AIM in the UK, less than 250 disclose information on their environmental sustainability practices. Thus, this study may help policymakers to introduce measures that may encourage SMEs particularly AIM listed firm to report on their environmental sustainability practices. The study also provides evidence that resource constraint, particularly, financial resources could affect SMEs ability to engage in environmental management practices. Thus, the government and other policymakers could offer some financial incentives to SMEs with resource constraint to improve on their environmental practices. Despite the several contributions provided by the study, like all other studies, it faces some limitations. First, the study depended mainly on content analysis of the annual reports to obtain information on environmental sustainability measures of selected firms. Thus, other environmental practices not reported in the annual reports or the selected company's websites were not captured in the study. The study also solely relied on quantitative disclosure which was more available instead of qualitative data. 


\section{References}

1. Afrifa, G. A. (2013) Working Capital and Listed SMEs Profitability: A Mixed Research Method Approach. Bournemouth.

2. Aiyub, K. et al. (2009) 'environmental performance in SMEs certified to ISO14001 in the UK.pdf.

3. Allayannis, G. and Mozumdar, A. (2004) 'The impact of negative cash flow and influential observations on investment-cash flow sensitivity estimates', Journal of Banking and Finance, 28(5), pp. 901-930. doi: 10.1016/S0378-4266(03)00114-6.

4. Almeida, H., Campello, M. and Weisbach, M. S. (2004) 'The Cash Flow Sensitivity of Fash', Journal of Finance, 59(4), pp. 1777-1804. doi: 10.1111/j.1540-6261.2004.00679.x.

5. Ambec, S. et al. (2013) 'The Porter hypothesis at 20: can environmental regulation enhance innovation and competitiveness?', Review of Environmental Economics and Policy (January), p. res016.

6. Arslan, Ö., Florackis, C. and Ozkan, A. (2006) 'The role of cash holdings in reducing investment-cash flow sensitivity: Evidence from a financial crisis period in an emerging market', Emerging Markets Review, 7(4), pp. 320-338. doi: 10.1016/j.ememar.2006.09.003.

7. Barney, J. (1991) 'Barney, J. (1991). Firm Resources and Sustained Competitive Advantage. Journal of Management, 17(1), 99-120. http://doi.org/10.1177/014920639101700108Firm Resources and Sustained Competitive Advantage', Journal of Management, pp. 99-120. doi: 10.1177/014920639101700108.

8. Berger, A. N. and Udell, G. F. (1995) 'Relationship Lending and Lines of Credit in Small Firm Finance', The Journal of Business, 68(3), p. 351. doi: 10.1086/296668.

9. Carter, C. R., Kale, R. and Grimm, C. M. (2000) 'Environmental purchasing and firm performance: An empirical investigation', Transportation Research Part E: Logistics and Transportation Review, 36(3), pp. 219-228. doi: 10.1016/S1366-5545(99)00034-4.

10. Christmann, P. (2000) 'Effects of "best practices" of environmental management on cost advantage: The role of complementary assets', Academy of Management Journal, 43(4), pp. 663-680. doi: 10.2307/1556360.

11. Clark, G. L., Feiner, A. and Viehs, M. (2015) 'From the Stockholder to the Stakeholder: How Sustainability Can Drive Financial Outperformance', SSRN Electronic Journal, (March), p. 63. doi: 10.2139/ssrn.2508281.

12. Cleary, S. (1999) 'The relationship between firm investment and financial status', Journal of Finance, 54(2), pp. 673-692. doi: 10.1111/0022-1082.00121.

13. Cleary, S. (2006) 'International corporate investment and the relationships between financial constraint measures', Journal of Banking and Finance. doi: 10.1016/j.jbankfin.2005.03.023.

14. Clemens, B. (2006) 'Economic incentives and small firms: Does it pay to be green?', Journal of Business Research, 59(4), pp. 492-500. doi: 10.1016/j.jbusres.2005.08.006.

15. DEFRA (2013) 'Conversion Factors for Company Reporting: Methodology Paper for Emission Factors', Defra, (October), p. 59. doi: v 1.2.1 final. 
16. Denis, D. J. and Sibilkov, V. (2010) 'Financial constraints, investment, and the value of cash holdings', Review of Financial Studies, 23(1), pp. 247-269. doi: 10.1093/rfs/hhp031.

17. Earnhart, D. and Lizal, L. (2007) 'Effect of pollution control on corporate financial performance in a transition economy', European Environment, 266, pp. 247-266. doi: 10.1002/eet.

18. Elsayed, K. and Paton, D. (2009) 'The impact of financial performance on environmental policy: Does firm life cycle matter?', Business Strategy and the Environment, 18(6), pp. 397-413. doi: 10.1002/bse.608.

19. Endrikat, J., Guenther, E. and Hoppe, H. (2014) 'Making sense of conflicting empirical findings: A metaanalytic review of the relationship between corporate environmental and financial performance', European Management Journal. Elsevier Ltd, 32(5), pp. 735-751. doi: 10.1016/j.emj.2013.12.004.

20. Environment Agency (2003) 'SME-environment'. Available at:http://www.netregs.org.uk/pdf/sme_2003_uk_1409449.pdf.

21. Fauzi, H. and Idris, K. M. (2009) 'The Relationship of CSR and Financial Performance: New Evidence from Indonesian Companies', Issues in Social \& Environmental Accounting, 3(1), pp. 66-87. Available at: http://search.ebscohost.com/login.aspx?direct=true\&db=bth\&AN=55149252\&site=ehost-live\&scope $=$ site.

22. Fazzari, S. M., Hubbard, R. G. and Petersen, B. C. (1988) 'Financing Constraints and Corporate Investment.', Brookings Papers on Economic Activity, (1), pp. 141-206. doi: 10.3386/w2387.

23. Fazzari, S. M., Hubbard, R. G. and Petersen, B. C. (2000) 'Investment-cash flow sensitivities are useful: A comment on Kaplan and Zingales', Quarterly Journal of Economics. doi: 10.1162/003355300554773.

24. Field, A. (2013) 'Discovering Statistics Using IBM SPSS Statistics', Discovering Statistics using IBM SPSS Statistics, pp. 297-321. doi: 10.1016/B978-012691360-6/50012-4.

25. Filbeck, G. and Gorman, R. F. (2004) 'The relationship between the environmental and financial performance of public utilities', Environmental \& Resource Economics, 29(2), pp. 137-157. doi: 10.1023/B:EARE.0000044602.86367.ff.

26. Gilchrist, S. and Himmelberg, C. P. (1995) 'Evidence on the role of cash flow for investment', Journal of Monetary Economics, 36(3), pp. 541-572. doi: 10.1016/0304-3932(95)01223-0.

27. Gómez-Bezares, F., Przychodzen, W. and Przychodzen, J. (2017) 'Bridging the gap: How sustainable development can help companies create shareholder value and improve financial performance', Business Ethics, 26(1), pp. 1-17. doi: 10.1111/beer.12135.

28. Hagel, J. et al. (2013) 'Success or struggle : ROA as a true measure of business performance', Deloitte University Press, pp. 4-18.

29. Hart, S. L. (1995) 'A natural - resource-based view of the firm’, Academy Management Review, 20(4), pp. 9661014.

30. Hart, S. L. and Ahuja, G. (1996) 'Does it pay to be green? An empirical examination of the relationship between emission reduction and firm performance', Business Strategy and the Environment, 5(1), pp. 30-37. doi: 10.1002/(SICI)1099-0836(199603)5:1<30::AID-BSE38>3.0.CO;2-Q.

31. Hillary, R. and Burr, P. (2011) 'Evidence-based Study into the Benefits of EMSs for SMEs (EV0440).', Final 
Report to the Department for Environment, Food and Rural Affairs, (September), pp. 1-145.

32. Horváthová, E. (2012) 'The impact of environmental performance on firm performance: Short-term costs and long-term benefits?', Ecological Economics. Elsevier B.V., 84, pp. 91-97. doi: 10.1016/j.ecolecon.2012.10.001.

33. Juan Felipe Reyes-Rodríguez; John P. Ulhøi; Henning Madsen (2014) 'Corporate Environmental Sustainability in Danish SMEs: A Longitudinal Study of Motivators, Initiatives, and Strategic Effects', Corporate Social Responsibility and Environmental Management.

34. Kline, R. B. (2010) 'Promise and pitfalls of structural equation modeling in gifted research.', in Methodologies for conducting research on giftedness, pp. 147-169. doi: 10.1037/12079-007.

35. Konar, S. and Cohen, M. A. (2001) 'Does the Market Value Environmental Performance?', Review of Economics and Statistics, 83(2), pp. 281-289. doi: 10.1162/00346530151143815.

36. Li, M. Y. L. and Hwang, N. C. R. (2011) 'Effects of Firm Size, Financial Leverage and R\&D Expenditures on Firm Earnings: An Analysis Using Quantile Regression Approach', Abacus, 47(2), pp. 182-204. doi: 10.1111/j.1467-6281.2011.00338.x.

37. López-Gamero, M. D., Molina-Azorín, J. F. and Claver-Cortés, E. (2009) 'The whole relationship between environmental variables and firm performance: Competitive advantage and firm resources as mediator variables', Journal of Environmental Management, 90(10), pp. 3110-3121. doi: 10.1016/j.jenvman.2009.05.007.

38. Martínez-Ferrero, J. and García-Sánchez, I. M. (2017) 'Sustainability assurance and cost of capital: Does assurance impact on credibility of corporate social responsibility information?', Business Ethics, 26(3), pp. 223239. doi: $10.1111 /$ beer.12152.

39. Melnyk, S. a., Sroufe, R. P. and Calantone, R. (2003) 'Assessing the impact of environmental management systems on corporate and environmental performance', Journal of Operations Management, 21(3), pp. 329-351. doi: 10.1016/S0272-6963(02)00109-2.

40. Montabon, F., Sroufe, R. and Narasimhan, R. (2007) 'An examination of corporate reporting, environmental management practices and firm performance', Journal of Operations Management. doi: 10.1016/j.jom.2006.10.003.

41. Ntim, C.; Soobaroyen, T. (2013) 'Corporate Governance and Performance in Socially Responsible Corporations: New Empirical Insights from a Neo-Institutional Framework', Corporate Social Responsibility, 21(5), pp. $468-494$.

42. Russo, V. M. and Fouts, A. P. (1997) 'A resource-based perspective on corporate environmental performance and profitability’, 40(3), pp. 534-559.

43. Scheuten, G. (2014) 'The influence of financial constraints on the investment - cash flow sensitivity in Dutch SMEs on the investment-cash flow sensitivity in Dutch SMEs', Master Thesis University Of Twente.

44. Thurner, T. and Proskuryakova, L. N. (2014) 'Out of the cold - the rising importance of environmental management in the corporate governance of Russian oil and gas producers', Business Strategy and the Environment. doi: $10.1002 /$ bse. 1787 .

45. Trumpp, C. et al. (2013) 'Definition, Conceptualization, and Measurement of Corporate Environmental Performance: A Critical Examination of a Multidimensional Construct', Journal of Business Ethics, 126(2), pp. 
185-204. doi: 10.1007/s10551-013-1931-8.

46. Trumpp, C. and Guenther, T. (2017) 'Too Little or too much? Exploring U-shaped Relationships between Corporate Environmental Performance and Corporate Financial Performance', Business Strategy and the Environment, 26(1), pp. 49-68. doi: 10.1002/bse.1900.

47. Vijfvinkel, S., Bouman, N. and Hessels, J. (2011) 'Environmental sustainability and financial performance of SMEs', Analysis, (January).

48. Wiengarten, F. and Pagell, M. (2012) 'The importance of quality management for the success of environmental management initiatives', International Journal of Production Economics. doi: 10.1016/j.ijpe.2012.06.024. 